\title{
LEGAL PROTECTION COPYRIGHT OF BULDING OF CULTURAL HERITAGE ARCHITECTURE (CASE STUDY OF ARCHITECTURAL ARCHITECTURE BUILDING IN CITY OF BOGOR)
}

\section{PERLINDUNGAN HUKUM PADA HAK CIPTA DALAM KARYA ARSITEKTUR BANGUNAN CAGAR BUDAYA (STUDI KASUS ARSITEKTUR BANGUNAN CAGAR BUDAYA DI KOTA BOGOR)}

\author{
Nurwati, J. Jopie Gilalo* \\ nurwati@unida.ac.id
}

(Diterima pada:05-06-2017 dan dipublikasikan pada:01-12.-2017)

\begin{abstract}
The change / delineation of buildings of cultural heritage architecture in Bogor City is not based on technical consideration, more on benefits and economics, and it is not in accordance / contrary to the provisions of Copyright Act No. 28 of 2014 on architectural works only allowed technical considerations. As the factor causing the nuance of the copyrighted works of cultural heritage architecture that many of the cultural heritage buildings that have moved from the first owner so that many in the total fox architecture of cultural heritage buildings that are also less effective legislation that brings people aware, because less socialization of legislation, the implementation of relatively light sanctions, lack of attention of local government in conservation efforts to the works of cultural heritage architecture. Due to the considerable cost. Efforts made to overcome the changes to the cultural heritage architectural work is to conduct good cooperation and coordination between institutions and related apparatus, to re-register and register in order to have the law, to give more severe sanction and firm, empower the buildings for example by way of functionalizing the building, increasing the role of architecture. This research is applicable law against culture heritage culture in Bogor city not yet implemented by law of Cultural Heritage and Copyright Act.
\end{abstract}

Keywords: Copyright, Heritage Sites

\section{ABSTRAK}

Perubahan/pengaliwujudan bangunan-bangunan karya arsitektur cagar budaya di Kota Bogor tidak berdasarkan pada pertimbangan teknis, tetapi lebih didasarkan pada pertimbangan manfaat dan ekonomis, dan hal itu tidak sesuai/bertentangan dengan kentuan Undang-undang Hak Cipta Nomor 28 Tahun 2014 yang menetapkan bahwa perubahan terhadap karya arsitektur hanya diperbolehkan berdasarkan pertimbangan pelaksanaan teknis. Adapun faktor penyebab timbulnya pelanggaran terhadap hak cipta karya arsitektur cagar budaya adalah banyak bangunan cagar budaya yang sudah berpindahtangan dari pemilik pertama sehingga banyak yang di rubah total arsitektur bangunan cagar budaya tersebut selain itu juga kurang efektifnya peraturan perundang-undangan yang disebabkan kurangnya kesadaran hukum masyarakat, karena kurangnya sosialisasi terhadap peraturan perundang-undangan, penerapan sanksi yang relatif masih ringan, kurangnya perhatian Pemerintah Daerah dalam upaya-upaya pelestarian terhadap karya-karya arsitektur cagar budaya. Disebabkan biaya pemeliharaan yang cukup besar. Upaya yang dilakukan untuk mengatasi pelanggaran terhadap karya arsitektur cagar budaya adalah melakukan 
kerjasama dan koordinasi yang baik antara lembaga dan aparatur terkait, melakukan pendataan ulang dan pendaftaran agar memiliki perlindungan hukum, memberikan sanksi yang lebih berat dan tegas, memberdayakan bangunan-bangunan misalnya dengan cara mengalihfungsikan bangunan, meningkatkan peran serta arsitek dalam rangka pelestarian karya arsitektur cagar budaya. Kesimpulan penelitian ini adalah bahwa perlindungan hukum terhadap karya arsitektur cagar budaya di Kota Bogor belum terlaksana sebagaimana seharusnya berdasarkan ketentuan Undang-undang Cagar Budaya dan Undang-undang Hak Cipta.

Kata Kunci : Hak Cipta, Cagar Budaya

\section{PENDAHULUAN}

Salah satu hal yang dapat mendukung pariwisata di kota Bogor adalah menjadikan bangunan cagar budaya sebagai tujuan pariwisata yang menarik. Karena bangunan cagar budaya mempunyai sifatsifat unik dan juga langka serta tidak bisa diperbaharui dan tidak bisa digantikan oleh teknologi dan juga bahan yang sama serta yang sangat penting adalah kesemuanya merupakan fakta aktifitas manusia pada masa lampau. Arsitektur bangunan cagar budaya di Kota Bogor sebagian besar adalah peninggalan pada jaman kolonial belanda yang mempunyai arsitektur yang khas berbeda dengan jaman sekrang, arsitektur bangunan cagar budaya ini ada yang masih utuh terpelihara dan ada juga yang sudah rusak dan dialih fungsikan.

Demikian besarnya peranan cagar budaya dalam dunia kepariwisataan di Indonesia, sehingga pemerintah menganggap perlu mengatur cagar budaya tersebut melalui peraturan perundang-undangan yang mengatur secara khusus tentang kepariwisataan. Pemerintah melalui UndangUndang Nomor 10 Tahun 2009 telah menyerahkan sebagian urusan di bidang kepariwisataan kepada Pemerintah Daerah yaitu seperti yang tercantum dalam Pasal 5 yang pada pokoknya menyatakan bahwa Pemerintah menyerahkan sebagian urusan di bidang penyelenggaraan kepariwisataan kepada Pemerintah Daerah.

Untuk lebih berhasilnya tujuan dari pengelolaan cagar budaya dalam upaya peningkatan pendapatan asli daerah tentunya dibutuhkan pengaturan ulang atau rekonstruksi hukum yang lebih memberdayakan sekaligus menjaga potensi cagar budaya tersebut.

Terkait cagar budaya yang merupakan salah satu hasil karya para leluhur bangsa Indonesia, hendaknya dapat diperlakukan sebaik mungkin. Untuk menumbuh kembangkan rasa ikut memiliki tentang khasanah ragam budaya bangsa Indonesia yang salah satunya dengan mengetahui, memahami dan menelusuri hasil karya budaya bangsa melalui tinggalan masa lalu, yang dewasa ini lebih dikenal sebagai cagar budaya. Rasa memiliki akan mendorong tingkat partisipasi masyarakat untuk ikut melestarikan aset budaya bangsa. Suatu kepunahan cagar budaya memang diakui disebabkan oleh beberapa hal, di antaranya alam, binatang dan manusia. Oleh sebab itu, bila Sumber Daya Manusia (SDM) mampu memahami pentingnya pelestarian cagar budaya, maka kepunahan sedini mungkin akan dapat dicegah. ${ }^{1}$

Hak cipta merupakan hak eksklusif bagi pencipta atau penerima hak untuk mengumumkan, ataupun memperbanyak ciptaannya, atau memberi izin untuk itu dengan tidak mengurangi pembatasanpembatasan menurut peraturan perundangan yang berlaku, mengandung arti bahwa selain

\footnotetext{
1 Agus Sarjono, Hak Kekayaan Intelektual Pengetahuan Tradisional" Alumni, Bandung 2010
} 
pencipta orang lain tidak berhak atasnya kecuali atas izin pencipta, karena hak tersebut muncul secara otomatis setelah suatu ciptaan dilahirkan. $^{2}$

Dalam penjelasan umum Undangundang No. 28 Tahun 2014 tentang Hak Cipta ditegaskan bahwa perlindungan hak cipta tidak diberikan kepada ide atau gagasan karena karya cipta harus mempunyai bentuk yang khas, bersifat pribadi dan menunjukan keaslian sebagai ciptaan yang lahir berdasarkan kemampuan, kreativitas atau keahlian sehingga ciptaan itu dapat dilihat, dibaca atau didengar.

Perkembangan pembangunan di Indonesia tidak terlepas dari peranan para arsitektur yang menghasilkan karya-karya hak cipta dalam bidang arsitektur, hal ini bisa terlihat dengan jelas terutama pembangunan aspek fisiknya, dimana banyak sekali terdapat bangunan-bangunan indah dan megah dengan gaya arsitektur yang bervariasi antara satu dengan yang lain. Konstruksi bangunan tersebut bisa berupa rumah tinggal, perkantoran, pusat perbelanjaan, pusat rekreasi, dan lainnya, yang mempunyai nilai artistik yang khas dan unik dengan gaya-gaya arsitektur yang indah.

Saat ini bangunan-bangunan tua peninggalan jaman kolonial Belanda tersebut sudah banyak yang dirubah, dibongkar, baik sebagian ataupun seluruhnya, atau dibiarkan tidak terawat, padahal bangunan-bangunan tua tersebut merupakan karya arsitektur peninggalan sejarah yang ditetapkan sebagai cagar budaya yang dilindungi.

Dalam ketentuan Undang-Undang Hak Cipta No. 28 Tahun 2014 maupun dalam ketentuan Undang-Undang Nomor 11 Tahun 2010 yang khusus mengatur tentang Cagar Budaya, ditetapkan bahwa karya arsitektur yang merupakan cagar budaya dilindungi oleh negara, baik dengan cara menguasai

2 OK Saidin, Aspek Kekayaan Intelektual (Intelektual Property Right), PT. Raja Grafindo Persada, Jakarta 2004, Hlm.56 karya arsitektur, maupun sebagai pemegang hak cipta atas karya aritektur tersebut. ${ }^{3}$

Perubahan atas karya arsitektur dalam ketentuan Undang-Undang Hak Cipta hanya diperbolehkan berdasarkan pertimbangan teknis, dan dalam ketentuan Undang-Undang Cagar Budaya, hanya diperbolehkan berdasarkan pada pertimbangan teknis, historis, dan arkeologis, dalam rangka mengembalikan keandalan bangunan dengan tetap memerhatikan keaslian bentuk bangunan asal. ${ }^{4}$

Hal ini menunjukan bahwa tidak ada benturan atau pertentangan antara UndangUndang No. 28 Tahun 2014 tentang Hak Cipta dengan Undang-Undang No. 11 Tahun 2010 tentang Cagar Budaya sebagai ketentuan yang lebih khusus. ${ }^{5}$

Penguasaan oleh negara terhadap karya arsitektur itu sendiri maupun hak ciptanya dalam rangka memberikan perlindungan hukum terhadap karya-karya arsitektur yang merupakan cagar budaya. Penguasaan oleh negara tersebut diatur melalui Undang-Undang No. 11 Tahun 2010 tentang Cagar Budaya, disebutkan dalam Pasal 90 bahwa "Pemanfaatan dengan cara perbanyakan Benda Cagar Budaya yang dimiliki dan/atau dikuasai setiap orang atau dikuasai negara dilaksanakan sesuai dengan ketentuan peraturan perundang-undangan", dan dalam ketentuan UU Hak Cipta No. 28 Tahun 2014 diatur dalam Pasal 40 ayat (1) huruf $h$ yang menyatakan bahwa karya arsitektur yang merupakan ciptaan yang dilindungi. Selanjutnya dalam Pasal 1 ayat (1) UU No. 11 Tahun 2010 tentang Cagar Budaya, yang dimaksud dengan cagar budaya adalah warisan budaya bersifat kebendaan berupa Benda Cagar Budaya, Bangunan Cagar Budaya, Struktur Cagar Budaya, Situs Cagar Budaya, dan Kawasan Cagar Budaya di darat dan/atau di air yang perlu dilestarikan keberadaannya karena

\footnotetext{
3 OK Saidin, Aspek Kekayaan Intelektual (Intelektual Property Right,) PT. Raja Grafindo Persada, Jakarta 2004 Hal.56 ${ }^{4}$ Ibid

${ }^{5}$ Ibid
} 
memiliki nilai penting bagi sejarah, ilmu pengetahuan, pendidikan, agama, dan/atau kebudayaan melalui proses penetapan. Sedangkan dalam pasal 1 ayat (3) yang dimaksud Bangunan Cagar Budaya ialah susunan binaan yang terbuat dari benda alam atau benda buatan manusia untuk memenuhi kebutuhan ruang berdinding dan/atau tidak berdinding, dan beratap.

Bangunan-bangunan tua peninggalan kolonial tersebut merupakan aset yang sangat penting bagi peradaban dan kebudayaan bangsa. Dalam penjelasan UU RI No. 11 Tahun 2010 tentang Cagar Budaya, yang ketentuannya dinyatakan juga dalam UndangUndang Dasar 1945, UUD 1945 Pasal 32 menegaskan bahwa pemerintah memajukan kebudayaan nasional Indonesia, serta penjelasannya antara lain menyatakan usaha kebudayaan harus menuju kepada kemajuan adab, budaya, dan persatuan dengan tidak menolak bahan-bahan baru dari kebudayaan asing yang dapat memperkembangkan atau memperkaya kebudayaan bangsa sendiri serta mempertinggi derajat kemanusiaan bangsa Indonesia.

Pembangunan di daerah yang mengutamakan pertumbuhan ekonomi telah menghasilkan perubahan dan kemakmuran. Akan tetapi di sisi lain, pembangunan itu juga ikut andil dalam mengorbankan lingkungan alam dan warisan budaya. Warisan budaya yang terkena dampak langsung pembangunan terutama berupa bangunan-bangunan dan peninggalanpeninggalan kuno lainnya, yang dikenal sebagai cagar budaya. Padahal secara kognitif juga cultural, cagar budaya menandai tata nilai, perjalanan, sejarah juga tradisi bangsa.

Dalam konsideran Undang-undang Hak Cipta dinyatakan bahwa, Undangundang ini dikeluarkan dalam rangka merealisasi amanah Garis-garis Besar Haluan Negara (GBHN) tahun 1978, khususnya pembangunan di bidang hukum yang dimaksudkan untuk mendorong dan melindungi pencipta dan hasil karya ciptaannya, dengan demikian diharapkan penyebar luasan hasil kebudayaan dibidang karya ilmu, seni dan sastra dapat dilindungi secara yuridis yang pada gilirannya dapat mempercepat proses pertumbuhan kecerdasan kehidupan bangsa. ${ }^{6}$

Hak cipta merupakan hak eksklusif bagi pencipta atau penerima hak untuk mengumumkan, ataupun memperbanyak ciptaannya, atau juga memberi izin untuk itu dengan tidak mengurangi pembatasanpembatasan menurut peraturan perundangan yang berlaku, mengandung pengertian bahwa selain pencipta orang lain tidak berhak atasnya kecuali atas izin pencipta, karena hak tersebut timbul secara otomatis setelah suatu ciptaan dilahirkan. ${ }^{7}$

Meskipun telah ditetapkan bahwa benda cagar budaya tersebut merupakan peninggalan sejarah yang sangat penting sehingga dikuasai dan dilindungi oleh negara, tetapi kenyataannya masih sangat memprihatinkan, pembangunan kota menuju kota metropolitan atau megapolitan disisi lain merupakan ancaman bagi berdirinya bangunan-bangunan atau kawasan yang telah ditetapkan sebagai cagar budaya.

Penggunaan pusaka budaya sebagai sumber dari kreatifitas kontemprorer dipandang dapat memberikan kontribusi terhadap pengembangan ekonomi dari masyarakat tradisional, misalnya melalui pendirian perusahaan rakyat, pembukaan lapangan pekerjaan ditingkat Lokal, pengembangan keahlian, pariwisata dan pendapatan dari luar negeri sebagai hasil dari mengekspor produk masyarakat. ${ }^{8}$

Preservasi dan konservasi bangunan dan benda bersejarah merupakan kata-kata yang sering diperdengarkan pada wacana publik sehubungan dengan perlindungan dan pelestarian terhadap bangunan-bangunan peninggalan sejarah atau yang lazim disebut

\footnotetext{
${ }^{6}$ Rosdinar Sembiring "jurnal Equality” Volume 11 No.2

${ }^{7}$ Ibid, hlm. 63

${ }^{8}$ http://www/lkht.net.php.option.com=articel warisan budaya hki telematika diakses pada tanggal 6 feb 2016
} 
sebagai cagar budaya, terutama di kota-kota yang memiliki sejarah panjang. ${ }^{9}$

Sejarah tersebut meninggalkan jejakjejak yang tampak, diantaranya dalam bentuk bangunan-bangunan kuno / bersejarah. Beberapa diantaranya dalam keadaan terawat baik, sementara banyak lagi yang dibiarkan merana tidak terawat untuk kemudian hilang ditelan waktu. Diantara yang masih tersisa, banyak juga yang akan dihilangkan secara sengaja dengan berbagai alasan, yang umumnya bermuara pada tudingan bahwa bangunan tersebut sudah tidak lagi sama dengan zaman, atau dianggap sebagai penghalang modernisasi. Bangunanbangunan yang memiliki nilai sejarah tersebut dianggap harus disingkirkan dan diganti dengan bangunan yang lebih modern dan up to date. ${ }^{10}$

Sementara itu penyingkiran bangunan-bangunan bersejarah tersebut ditentang oleh sekelompok masyarakat lain, yang menilai bahwa bangunan bangunan itu merupakan harta yang tidak ternilai harganya, serta tidak dapat diukur dengan uang atau kepentingan ekonomi, sehingga keberadaannya wajib untuk dilindungi dan dilestarikan. ${ }^{11}$

Karya arsitektur adalah ciptaan yang tidak kalah pentingnya dalam jajaran perlindungan hak cipta. Pentingnya perlindungan yang memadai terhadap arsitektur bisa dikaitkan dengan aspek pengembangan kebudayaan dan aspek potensi ekonomi, dimana arsitektur juga dapat dijadikan alat kontrol terhadap kejahatan. ${ }^{12}$

Dilihat dari sudut kontrol terhadap kejahatan, arsitektur melalui suatu perancangan lingkungan yang berwawasan keamanan bisa mendorong terjadinya kontrol sosial alami, sehingga pada akhirnya perancangan arsitektur disesuaikan dengan

\footnotetext{
${ }^{9}$ Suyud Margono, Hukum Kekayaan Intelektual (HKI), Pustaka Reka Cipta, Bandung, Hlm. 67

${ }^{10}$ Ibid

${ }^{11}$ Ibid

${ }^{12}$ Eko Budirahardjo, dalam Satjipto Rahardjo, et.all, Arsitek dan

Arsitektur Indonesia, Andi Yogyakarta, Yogyakarta, 1997, Hlm. 116.
}

tabiat, kebiasaan, kultur, serta perilaku suatu masyarakat. ${ }^{13}$

Dilihat dari sudut pengembangan kebudayaan, arsitektur mencerminkan dan membawa nilai-nilai budaya bangsa yang sifatnya dan/atau mempunyai ciri khas. Oleh karena itu, keberadaannya perlu dilestarikan dan dikembangkan dalam rangka mempertahankan kepribadian dan nilai-nilai budaya Indonesia. Arsitektur sebagai salah satu hasil karya budaya, bisa dijadikan petunjuk bagi pengembangan budaya suatu bangsa, karena perkembangan kebudayaan dapat ditelusuri melalui perkembangan arsitektur.

Dalam ketentuan UU No. 28 Tahun 2014 tentang Hak Cipta, ditentukan bahwa terhadap karya arsitektur tidak boleh dilakukan perubahan / pengalihwujudan baik secara permanen maupun temporer terhadap keseluruhan maupun bagian yang sangat sunstansial dari karya arsitektur tersebut, baik dengan menggunakan bahan-bahan yang sama maupun tidak sama, karena hal itu merupakan suatu pelanggaran terhadap hak cipta. $^{14}$

Perubahan terhadap karya arsitektur hanya boleh dilakukan berdasarkan pertimbangan pelaksanaan teknis. Meskipun dimungkinkan dilakukan perubahan terhadap karya arsitektur karena pertimbangan teknis, namun mengacu pada UU No. 11 Tahun 2010 tentang Cagar Budaya dan UU No. 28 Tahun 2002 tentang Bangunan Gedung, perubahan terhadap karya arsitektur yang merupakan cagar budaya dilakukan sematamata untuk memperbaiki dan mengembalikan keandalan bangunan tersebut, tanpa harus merubah bentuk aslinya. ${ }^{15}$

Mengenai bangunan-bangunan peninggalan kolonial Belanda yang telah ditetapkan sebagai cagar budaya, pada dasarnya bangunan-bangunan tersebut telah memenuhi persyaratan teknis bagunan, hal tersebut dapat dilihat diantaranya pada konstruksi bangunan, kekuatan bangunan

\footnotetext{
${ }^{13}$ Ibid

${ }^{14}$ Lihat dalam penjelasan undang-undang Repub.lik Indonesia Nomor 28 tahun2014 tentang Hak Cipta

${ }^{15}$ Lihat Undang-Undang no.28 tahun 2002 tentang Bangunan Gedung
} 
dalam menahan beban, pemilihan bahan, dan detail-detail lainnya yang menunjukan suatu hasil karya arsitektur yang sangat luar biasa, kalaupun kemudian bangunan tersebut secara teknis menjadi tidak laik fungsi hal itu disebabkan karena kerusakan-kerusakan yang terjadi, misalnya keadaan atap bangunan yang rusak dan rapuh, sehingga dapat membahayakan keselamatan, maka bukan berarti atap tersebut harus dirubah atau bahkan dibongkar, melainkan seharusnya diperbaiki untuk mengembalikan keandalannya sehingga menjadi laik fungsi kembali. ${ }^{16}$

$$
\begin{array}{ccc}
\text { Hal ini membuat Pemerintah Daerah } \\
\text { bersangkutan leluasa untuk }
\end{array}
$$
memutuskan apakah suatu bangunan tetap dipertahankan atau dibongkar karena keberadaannya dianggap sudah tidak layak terutama secara ekonomis, meskipun bangunan tersebut merupakan bangunan yang dilindungi sebagai cagar budaya.

Sedangkan pengelolaan terhadap bangunan-bangunan tersebut dilakukan melalui 3 (tiga) cara, yaitu :

1. Sistim kerjasama, bangunan diserahkan kepada pihak ketiga untuk dikelola.

2. Sistim sewa, bangunan disewakan pada pihak lain, berdasarkan persetujuan dari Dewan Perwakilan Rakyat.

3. Diberdayakan, bangunan dikelola oleh Pemerintah Daerah melalui instansi tertentu.

Meskipun Pemerintah Daerah beralasan pembongkaran bangunan cagar budaya yang diganti dengan bangunan komersial dilakukan atas dasar manfaat, namun, para pemerhati dan ahli bangunan bersejarah menilai pemanfaatan bangunan cagar budaya seharusnya dilakukan dengan tetap memperhatikan keaslian bentuk bangunan asal.

\section{METODE PENELITIAN}

Metode yang digunakan dalam penelitian ini, peneliti akan mendapatkan data atau fakta-fakta, serta keteranganketerangan dari sumber yang dapat dipercaya dan dapat dipertanggungjawabkan kebenarannya. Adapun sistematis metode penelitian adalah sebagai berikut: ${ }^{17}$

1. Jenis/Tipe Penelitian dan Pendekatan Masalah.

Jenis penelitian yang digunakan dalam penelitian ini adalah deskriptif, yaitu jenis penelitian yang sifatnya mendeskripsikan atau menjelaskan peraturan-peraturan yang ada dan saat ini berlaku sebagai hukum positif dan bertujuan untuk memahami penerapan norma-norma hukum terhadap faktafakta.

Sedangkan pendekatan masalah yang dipergunakan dalam penelitian ini adalah pendekatan yuridis empiris/sosiologis, yaitu pendekatan terhadap hukum sebagai suatu norma atau kaidah dan pendekatan terhadap masyarakat dalam arti melihat realita yang ada di masyarakat untuk identifikasi terhadap faktor-faktor yang berperan dalam peristiwa hukum yang bersangkutan.

Berdasarkan tipe penelitian yang digunakan untuk melakukan penelitian ini ialah penelitian yuridis empiris/ sosiologis, maka pendekatan masalah yang digunakan peneliti adalah pendekatan perundang-undangan (statute approach) yang terkait dengan permasalahan yang diteliti serta pendekatan melalui wawancara (interview) terkait permasalahan yang diteliti.

2. Metode Pengumpulan Data

Data yang diperlukan dalam penelitian hukum ini adalah data primer dan data sekunder. Dalam penelitian ini, bahan hukum yang digunakan adalah:

a. Bahan Hukum Primer.

\footnotetext{
${ }^{17}$ Peter Mahmud Marzuki, Penelitian Hukum, Prenada Media, Jakarta, 2005, Hlm. 4.
} 
Yaitu bahan hukum terkait dengan bahan hukum yang bersifat mengikat yang terkait dengan peraturan perundangundangan yang bersifat hierarki. ${ }^{18}$ Bahan hukum lain yang digunakan adalah bahan hukum yang bersifat autoritatif artinya mempunyai otoritas. ${ }^{19}$ Diantaranya bahan hukum yang mengikat dan terdiri dari Undang-Undang Nomor 28 Tahun 2014 Tentang Hak Cipta,

Undang-undang Nomor 11 tahun 2010 tentang Cagar Budaya.

\section{b. Bahan Hukum Sekunder.}

Yaitu bahan hukum yang berupa semua publikasi tentang hukum yang bukan merupakan dokumen-dokumen resmi. ${ }^{20}$ Publikasi tersebut berupa buku teks (text books) tentang hukum yang ditulis para ahli hukum, makalah dan lainnya yang berkaitan dengan apa yang diteliti.

\section{c. Bahan Hukum Tersier.}

Yaitu bahan hukum yang memberikan petunjuk maupun penjelasan yang bermakna terhadap bahan hukum primer dan sekunder. ${ }^{21}$ Seperti kamus hukum dan ensiklopedia hukum.

\section{HASIL DAN PEMBAHASAN}

Berdasarkan hasil penelitian yang di peroleh di lapangan keseluruhan hasil pendataan awal jumlah bangunan cagar budaya (BCB) di Kota Bogor tercatat ada 426 bangunan cagar budaya, yang terdiri dari Bangunan Pemerintah, Bangunan Pendidikan, Militer, Sosial, Penelitian dll. Dari jumlah tersebut sebanyak 24 BCB telah di daftarkan dan mendapat SK Menteri Kebudayaan dan Pariwisata pada tahun 2007. ${ }^{22}$ Dengan perkembangan kota dan pertumbuhan penduduk di Kota Bogor menjadi salah satu pentebab hilangnya sejumlah bangunan

\footnotetext{
${ }^{18}$ Johnny Ibrahim, Op.cit, Hlm. 338.

${ }^{19}$ Peter Mahmud Marzuki, Op.cit, Hlm. 141.

${ }^{20}$ Ibid.

${ }^{21}$ Johnny Ibrahim, Loc.cit, Hlm. 338.

${ }^{22}$ Data Inventarisasi Cagar Budaya kota Bogor Tahun 2015, Dinas Kebudayaan Pariwisata Dn Ekonomi Kreatif Kota Bogor.
}

peninggalan sejarah, maka dengan pendataan ulang ini bisa mengurangi masyarakat untuk tidak merubah bangunan yang termasuk bangunan cagar budaya.

Dari jumlah keseluruhan ada yang belum terdata, karena masih banyak dari bangunan cagar budaya tersebut yang telah berpindah fungsi dan hilang karena pembangunan, seperti menjadi factory Outlet, dan restoran/cafe, hal itu dikarenakan bangunan cagar budaya tersebut itu menjadi milik pribadi, sehingga ketika diwariskan kepada anak-anaknya, mereka merenovasi atau bahkan menjual kepada pihak lain. Sehingga bangunan yang awalnya merupakan peninggalan kolonia Belanda menjadi hilang sejarahnya.

Dari hasil penelitian dilapangan juga peneliti mencatat bangunan bersejarah yang termasuk kategori cagar budaya di kota bogor berdasarkan kecamatan adalah sebagai berikut:

Tabel 1

Jumlah Bangunan Cagar Budaya di Kota Bogor berdasarkan kecamatan

\begin{tabular}{lll}
\hline No. & Kecamatan & Jumlah \\
\hline 1. & Bogor Utara & 96 \\
2. & Tanah Sereal & 20 \\
3. & Bogor Tengah & 228 \\
4. & Bogor Timur & 29 \\
5. & Bogor Barat & 29 \\
6. & Bogor Selatan & 426 \\
& Jumlah & 828 \\
\hline
\end{tabular}

Setelah mengetahui jumlah bangunan cagar budaya di kota Bogor selanjutkan peneliti melanjutkan dengan penyebaran angket yang di lakukan secara acak mulai dari pegawai dinas kebudayaan dan juga pariwisata sampai dengan lapisan masyarakat, data yang didapat pada pelaksanaan penelitian ini sebagai data pendukung, peneliti mendapatkan data dan informasi secara langsung mengenai pengetahuan masyarakat selaku Arsitektur Bangunan Cagar Budaya (BCB) di Kota Bogor. Hasil dari sebar responden yang disebarkan pada umumnya masyarakat mengetahui sejarah BCB 
kabupaten Bogor, namun mengenai PERDA yang berhubungan dengan BCB pada umumnya tidak mengetahui, Pengalih fungsikan $\mathrm{BCB}$ masyarakat umum sanngat menyetujui tertuma jika di alihfungsinya menjadi museum, perpustakaan . namun tidak merubah bentuk asli dari Bangunan Cagar Budaya.

Tanggapan mengenai terhadap kondisi bangunan cagar budaya serta perlunya penataan agar BCB tertata dengan rapih. Selain itu perawatan agar BCB tetap terjaga keasliannya membutuhkan biaya yang tidak sedikit. Itulah yang menyebabkan pemilik bangunan cagar budaya berupa rumah tinggal tidak melakukan perawatan secara baik, diperlukan arsitektur untuk memperbaiki bangunan yanng sudah lama tidak terawat agar kembali bisa di nikmati oleh pencinta dBCB dan masyarakat umum.

Lebih lanjut, agar lebih mengetahui sejauh mana Perlindungan Hukum Pada Hak Cipta Dalam Karya Arsitektur Bangunan Cagar Budaya di Kota Bogor, maka peneliti melakukan sebar angket (kuesioner) ke masyarakat dan pihak pemerintah yang berhubungan langsung dengan Bangunan Cagar Budaya, dari hasil sebar kuesioner menyebutkan pada umumnya masyarakat dan pihak pemerintah sangat puas terhadap perawatan dan pelestarian berupa preservasi, revitalisasi dan di pugar oleh arsitek yang bersertifikat. Peran serta pemerintah dalam memberikan izin renovasi, pemugaran atau bongkar sangat didukung .Dalam pelaksanaan pemugaran dilakukan oleh pihak pemerintah dan pemilik bangunan, namun BCB yang dikelola oleh pemerintah sebaiknya menggunakan dana APBD dengan tujuan sebagai pariwisata yang dimiliki daerah tersebut. Kemudian pihak pemerintah harus memebrikan sanksi yang tegas kepada pelaku yang melanggar atau memugar $\mathrm{BCB}$ dan merubah bentuk asli dari BCB tersebut.
JAWABAN

PERNYATAAN
KET.

PEMERINTAH

BCB dimanfaatkan menjadi ruang baru

Pemugaran didampingi

Kegiatan

Melestarikan/Merawat

Arsitektur Bangunan

Budaya di Kota Bogor

\section{Cagar}

oleh arsitek
Peran Serta Pemerintah dalam keberlangsungan Arsitektur Bangunan Cagar Budaya di Kota Bogor
Memberikan insentif bagi pemilik bangunan
Membangun kemitraan dengan swasta untuk mengelola $\mathrm{BCB}$

$\begin{array}{lllrlr}\text { Peran serta pemilik Bangunan } & \text { Diberikan } & \text { pelatihan } & \text { Membantu } & \text { memulihkan } \\ \text { Pengelola (PPP) } & \text { Bangunan } & \text { teknis } & \text { dalam } & \text { bangunan } & \text { ditelantarkan } \\ \text { Cagar Bersejarah } & \text { merawat } & & \text { ditang }\end{array}$

$\begin{aligned} & \text { Pelaksanaan kegiatan dalam } \\ & \text { merawat/melestarilkan }\end{aligned}$
$\begin{aligned} & \text { Bangunan Cagar Budaya di } \\ & \text { Kota Bogor }\end{aligned}$


Berdasarkan hasil penyebaran kuesioner kepada masyarakat (responden) yang dilakukan secara acak di wilayah Kota Bogor, bahwa kebanyakan warga Bogor tahu bangunan-bangunan Arsitektur Cagar Budaya di Kota Bogor tetapi tidak mengetahui undang-undang atau Peraturan Daerah yang mengatur tentang perlindungan Arsitektur Bangunan Cagar Budaya. Hal ini dikarenakan Kota Bogor belum memiliki Peraturan Daerah yang mengatur tentang hal tersebut.

Selain itu, masyarakat yang menikmati dari bangunan cagar budaya tersebut masih kurang menyadari pentingnya merawat/melestarikan arsitektur bangunan cagar budaya di Kota Bogor, khususnya. Apalagi ketidaktahuan pemilik dalam merawat/ memugar/ merevitalisasi bangunan tersebut menjadi salah satu faktor kerusakan dalam pengelolaan arsitektur bangunan cagar budaya. Selain itu juga pemilik bangunan yang bangunananya termasuk cagar budaya tidak memiliki biaya yang cukup untuk melestarikan bangunan tersebut yang mempertahankan keutuhan seperti bentuk aslinya.

Selain itu pula Pemerintah Kota Bogor belum memiliki peraturan daerah tentang Perlindungan Hukum terhadap Arsitektur Cagar Budaya di Kota Bogor. Karena peraturan tersebut belum diterbitkan pemerintah pun tidak bisa bergerak banyak sebab payung hukum-nya belum dimiliki oleh pemerintah Kota Bogor.

\section{KESIMPULAN DAN IMPLIKASI}

1. Perubahan/pengalihwujudan terhadap bangunan-bangunan yang merupakan karya arsitektur yang ditetapkan sebagai cagar budaya di kota Bogor ada beberapa yang tidak sesuai dengan ketentuan Undang-undang Hak Cipta di Indonesia, hal ini terbukti dengan dilakukannya beberapa perubahan terhadap karya aristektur yang merupakan cagar budaya. Adapun upaya Perlindungan Hukum terhadap hak cipta karya arsitektur bangunan cagar budaya tersebut disebabkan antara lain: a) Kurang efektifnya peraturan perundangundangan yang disebabkan karena kurang nya pengetahuan dan kesadaran hukum dalam masyarakat terhadap peraturan perundang-undangan yang berlaku, yang disebabkan kurangnya sosialisasi terhadap peraturan peundang-undangan itu sendiri.

b) Kurang kerjasama dan koordinasi yang baik antara kelembagaan dan aparat serta pihak-pihak terkait lainnya.

c) Penerapan sangsi yang relatif ringan karena sangksi yang diberikan hanya sanksi perdata berupa ganti rugi.

d) Bangungan berupa rumah tinggal banyak yang sudah berpindah tangan, ini yang menyebabkan arsitektur bangunan menjadi berubah total tidak seperti arsitektur aslinya, bahkan sudah beralih fungsi menjadi factory outlet, restoran, cafe tempat pendidikan dan lain-lain.

e) Materi dari perundangan undangan yang ada terkait pelestarian karya arsitektur bangunan cagar budaya kurang cukup memadai.

2. Upaya-upaya yang dapat dilakukan untuk mengatasi pelanggaran terhadap hak cipta karya arsitektur cagar budaya tersebut, antara lain adalah :

a) Melakukan kerjasama dan koordinasi yang baik antara aparatur terkait seperti ASN, aparat Polri dan TNI, Jaksa Agung, dan lainnya. Selain itu juga melakukan kerja sama dengan berbagai elemen kemasyarakatan lainnya di bidang Hak Cipta dalam penanggulangan pelanggaran Hak Cipta Cagar Budaya, seperti komunitas dan pemerhati pelstarian cagar budaya, arsitek, dan pihak-pihak lainnya yang memberikan kontribusi sehubungan dengan pelestarian.

b) Memberikan sanksi yang lebih berat dan tegas, misalnya dengan membebankan sanksi pidana (kurungan/penjara) dan sanksi perdata (ganti rugi) sekaligus. Agar lebih dapat memberikan efek jera terhadap sipelanggar.

c) Memberdayakan bangunan-bangunan cagar budaya dengan cara mengalih 
fungsikan bangunan, contohnya menjadi museum, perpustakaan umum tempat wisata lainnya , sehingga Selain mendapatkan keuntungan dari segi pelestarian budaya dan sejarah, Pemerintah daerah juga memperoleh keuntungan dari segi ekonomis, sehingga bisa menekan biaya pemeliharan dan pelestarian sehingga beban biaya pemeliharaan menjadi berkurang.

d) Meningkatkan Peran serta arsitek dalam rangka pelestarian karya arsitektur bangunan cagar budaya tersebut, sesuai dengan kode etik arsitek, seorang arsitek berkewajiban berperan aktif dalam pelestarian bangunan dan atau kawasan bersejarah / bernilai arsitektur yang tinggi, arsitek berkewajiban meneliti secara cermat sebelum melakukan rencana peremajaan, pembongkaran bangunan/kawasan yang dinilai memiliki potensi yang perlu dilestarikan, baik sebagian maupun seluruhnya, arsitek berkewajiban memberikan saran-sarannya melalui Ikatan Arsitek Indonesia Cabang apabila mengetahui ada rencana perombakan, peremajaan, pembongkaran bangunan, atau kawasan yang perlu dilestarikan.

\section{IMPLIKASI}

1. Melengkapi Undang-Undang Hak Cipta No. 28 Tahun 2014 dengan Peraturan pelaksananya, khususya di bidang Pengaturan Hak Cipta atas Karya
Arsitektur termasuk karya arsitektur Cagar Budaya.

2. Melakukan sosialisasi dan partisipasi secara terus menerus kepada masyarakat, guna meningkatkan kesadaran hukum masyarakat terhadap kecintaan kepada peninggalan bangunan bersejarah, dan memberikan informasi kepada masyarakat tentang ruang lingkup dan hal-hal lain yang menyangkut isi atau materi Undangundang dimaksud misalnya.

Melibatkan partisipasi masyarakat sedini mungkin dalam proses pelestarian cagar budaya tersebut, dengan cara mengintegrasikan bangunan cagar budaya tersebut dalam kehidupan masyarakat sehari-hari, misalnya dengan menggunakan bangunan-bangunan lama peninggalan kolonial tersebut sebagai penunjang kegiatan wisata yang dikelola oleh masyarakat disekitarnya, sehingga masyarakat akan memperoleh keuntungan dari segi ekonomi, dan hal tersebut akan menimbulkan / membangkitkan rasa memilki terhadap benda-benda bersejarah yang berada disekelilingnya, dan pada akhirnya akan menimbulkan rasa bangga dan kebutuhan untuk menjaga kelangsungan eksistensi dari benda-benda bersejarah tersebut karena benda-benda bersejarah itu mampu mendatangkan keuntungan bagi masyarakat sehingga mereka dapat memperbaiki perekonomiannya. 


\section{DAFTAR PUSTAKA}

\section{A. Buku-buku}

Agus Sarjono, Hak Kekayaan Intelektual Pengetahuan Tradisional, Alumni, Bandung 2010

Djumhana, Muhamad, dan R Djubaedillah, Hak Milik Intelektual (Sejarah, teori dan Prakteknya), Jakarta : PT. Grafindo Persada, 1997."

Djulaeka, Konsep Perlindungan Hak Kekayaan Intelektual, Setara Press, Malang, 2014

Data Inventarisasi Cagar Budaya Kota Bogor Tahun 2015, DISPARBUD

Eddy Damain, Hukum Hak Cipta, edisi ke-3, Cet.1, Alumni, Bandung 2009

Eko Budirahardjo, dalam Satjipto Rahardjo, et.all, Arsitek dan Arsitektur Indonesia, Andi Yogyakarta, 1997

Hendraningsih, Peran, Kesan, dan Bentuk-bentuk Arsitektur, Djambatan, Bandung, 1985

Henry soelistiyo, Hak Kekayaan Itelektual Konsepsi, Opini dan Aktualisasi, Penaku 2014 Setara Press, Malang, 2015

2011

”Plagiarisme Pelanggaran Hak Cipta dan Etika, Kanisius, Yogyakarta,

Kholis Roisah, Konsep Hukum Hak Kekayaan Intelektual,

Soejono Dirdjosisworo, Pengantar Hukum Dagang Inetnasional, Sinar Grafika, Jakarta, 2013

Saidin, Aspek Hukum Hak Kekayaan Intelektual (IntellectualProperty Rights), PT. Raja Grafindo Persada, Jakarta, 2004

Suyud Margono, Hukum Hak Kekayaan Intelektual (HKI), Pustaka Reka Cipta, Bandung, 2015

B. Karya Ilmiah

Rosdinar sembiring "Jurnal Equaliti Volume 11 No.2

United Nation Convention On Biological Diversity juga telah diratifikasi oleh Indonesia melalui Undang-undang Nomor 05 tahun 1994

Point 19 of the Minesterial Declaration adopted on 14 November 2001, Ministerial Conference of World Trade Organization, (Documnet No. WT/MIN(01)/Dec/1,20 November 2001)

Mundardjito, Research Method For Historical Urban Heritage Area, Makalah dipresentasikan pada Three Days Partical Course On Planning And Design

C. Peraturan-peraturan

Undang-undang Nomor 28 Tahun 2014 Tentang Hak Cipta (Lembaran Negara Republik Indonesia Tahun 2002/85; Tambahan Lembaran Negara Republik Indonesia Nomor 4220)

Undang-undang Nomor 11 Tahun 2010 Tentang Cagar Budaya (Lembaran Negara Republik Indonesia Tahun 1992/27; Tambahan Lembaran Negara Republik Indonesia Nomor 3516)

Surat Keputusan Majelis Arsitek Indonesia Nomor 10/MJS-IAI/SK/IX/1992 Tentang Kaedah Tata Laku Keprofesian Ikatan Arsitek Indonesia.

United Nation Convention On Biological Diversity juga telah diratifikasi oleh Indonesia melalui Undang-undang Nomor 05 tahun 1994 
D. Lain-Lain

http/www.hukumonline.com

http://www.lkht.net

http://augustrush15.files.worldpress.com 